\title{
6 Marriage as Exploitation: Emma Goldman and the Anarchist Concept of Female Liberation
}

\author{
Asked in an interview in 1897 "What does anarchy hold out to me-a woman?" \\ the famous American anarchist Emma Goldman (1869-1940) ${ }^{1}$ replied: "More to \\ [a] woman than to anyone else-everything which she has not-freedom and \\ equality."2 Goldman, whose feminist positions and role as a leading anarcha- \\ feminist have been discussed in recent works, ${ }^{3}$ was considered to be the "priest-
}

1 Many biographical works and edited volumes about Goldman's life and impact have been published, including Paul Avrich and Karen Avrich, Sasha and Emma: The Anarchist Odyssey of Alexander Berkman and Emma Goldman (Cambridge, MA: Belknap Press, 2014); Richard Drinnon and Anna Maria Drinnon, eds., Nowhere at Home: Letters from Exile of Emma Goldman and Alexander Berkman (New York: Schocken Books, 1975); Richard Drinnon, Rebel in Paradise: A Biography of Emma Goldman, Phoenix edition (Chicago: University of Chicago Press, 1982 [1961]); Candace Falk, Love, Anarchy and Emma Goldman (New Brunswick, NJ: Rutgers University Press, 1990 [1984]); Bonnie Haaland, Emma Goldman: Sexuality and the Impurity of the State (Montréal et al.: Black Rose Books, 1993); Vivian Gornick, Emma Goldman: Revolution as a Way of Life (New Haven, CT: Yale University Press, 2011); Joseph Ishill, Emma Goldman: A Challenging Rebel (Berkeley Heights, NJ: Oriole Press, 1957); Frank Jacob, Emma Goldman: Ein Leben für die Freiheit (Berlin: Hentrich \& Hentrich, 2021); Theresa Moritz and Albert Moritz, The World's Most Dangerous Women: A New Biography of Emma Goldman (Vancouver: Subway Books, 2002); David Porter, Vision on Fire: Emma Goldman on the Spanish Revolution (New Paltz, NY: Commonground Press, 1983); Alice Wexler, Emma Goldman: An Intimate Life (New York: Pantheon, 1984).

2 Emma Goldman, “What Is There in Anarchy for Woman?” St. Louis Post-Dispatch Sunday Magazine, October 14, 1897, 9, in Emma Goldman: A Documentary History of the American Years, vol. 1: Made for America, 1890-1901, eds. Candace Falk et al. (Urbana/Chicago, IL: University of Illinois Press, 2008), 289.

3 Kathy E. Ferguson, “Gender and Genre in Emma Goldman,” Signs 36, no. 3 (2011): 733-757; Frank Jacob, “Anarchismus, Ehe und Sex: Emma Goldman (1869-1940) als Anarcha-Feministin," in Geschlecht und Klassenkampf: Die "Frauenfrage" aus deutscher und internationaler Perspektive im 19. und 20. Jahrhundert, eds. Vincent Streichhahn and Frank Jacob (Berlin: Metropol, 2020), 202-221; Donna M. Kowal, "Anarcha-Feminism," in The Palgrave Handbook of Anarchism, eds. Carl Levy and Matthew S. Adams (Cham: Palgrave Macmillan, 2019), 265-279; Donna M. Kowal, Tongue of Fire: Emma Goldman, Public Womanhood, and the Sex Question (Albany, NY: SUNY Press, 2016); Lori Jo Marso, “A Feminist Search for Love: Emma Goldman on the Politics of Marriage, Love, Sexuality and the Feminine," Feminist Theory 4, no. 3 (2003): 305320; Penny A. Weiss and Loretta Kensinger, eds., Feminist Interpretations of Emma Goldman (University Park, PA: Pennsylvania State University Press, 2007).

Ә OpenAccess. () 2021 Frank Jacob, published by De Gruyter. (cc) BY-NC-ND This work is licensed under the Creative Commons Attribution-NonCommercial-NoDerivatives 4.0 International License.

https://doi.org/10.1515/9783110751451-006 
ess of anarchy" ${ }^{4}$ by many of her contemporaries, and often her female appearance surprised the men who met her: "She is in every sense a womanly looking woman, with masculine mind and courage." ${ }^{5}$ In fact, Goldman surprised many of her contemporaries, but not only with regard to her appearance but also with her ideas of unlimited freedom for everyone. She was praised as a "real champion of freedom"6 by those who supported her political struggles against exploitation, the state, or the dominance of patriarchy in American society, but she was also considered the evil personification of anarchism, ${ }^{7}$ which caused an "aura of menace around Emma Goldman." and American imperialism, ${ }^{9}$ as well as her support of the Russian Revolution, which she initially had high hopes for before realizing after her deportation to Soviet Russia that the revolutionary process had been corrupted by the Bolsheviks around Lenin, ${ }^{10}$ made the well-known anarchist one of the main targets of the new laws the US government used during the war to suppress resistance against the state's official war policy. When Goldman and many of her anarchist friends were deported in 1919, it was the young J. Edgar Hoover (1895-1972) who personally oversaw that "two of the most dangerous anarchists in America"11 were successfully expelled from the United States.

4 Goldman, "What Is There in Anarchy for Woman?” 289.

5 Ibid., 292.

6 Emma Goldman, An Anarchist Looks at Life, Text of a speech by Emma Goldman, held at Foyle's twenty-ninth literary luncheon (London, UK), March 1, 1933, Emma Goldman Papers, International Institute of Social History, Amsterdam (henceforth EGP-IISH), No. 191, 3.

7 Kowal, “Anarcha-Feminism,” 274.

8 Kathy E. Ferguson, "Discourses of Danger: Locating Emma Goldman,” Political Theory 36, no. 5 (2008): 743.

9 Frank Jacob, “Anarchistische Imperialismuskritik und staatliche Repression: Emma Goldman, Alexander Berkman und die Kritik an der politischen Ökonomie des Ersten Weltkrieges in den USA, 1917-1919,” Prokla 50, no. 201 (2020): 681-695; Erika J. Pribanic-Smith and Jared Schroeder, Emma Goldman's No-Conscription League and the First Amendment (New York: Routledge, 2019).

10 Frank Jacob, "Anarchism and the Perversion of the Russian Revolution: The Accounts of Emma Goldman and Alexander Berkman,” Diacronie 33, no. 1 (2018): https://doi.org/10.4000/ diacronie.7405; Frank Jacob, "Der Anarchismus und die Russische Revolution - Emma Goldman und Alexander Berkman im Kampf gegen den Bolschewismus," Ne znam: Zeitschrift für Anarchismusforschung 7 (2018): 3-66; Frank Jacob, Emma Goldman and the Russian Revolution: From Admiration to Frustration (Berlin: De Gruyter, 2020); Frank Jacob, "From Aspiration to Frustration: Emma Goldman's Perception of the Russian Revolution,” American Communist History 17, no. 2 (2018): $185-199$.

11 J. Edgar Hoover, “Memorandum for Mr. Creighton,” U.S. Department of Justice, August 23, 1919, 2, cited in Ferguson, "Discourses of Danger," 735. 
Goldman would nevertheless continue her "rebellious life" and criticized not only Bolshevism but also Fascism and National Socialism in the years that followed the beginning of her exile. ${ }^{12}$ Regardless of Goldman's many political struggles, the freedom of the modern woman was one essential aspect of her personal agenda, especially since women were far away from equality. For the anarchist Goldman, the woman "is the slave of her husband and her children. She should take her part in the business world the same as the man; she should be his equal before the world, as she is in the reality. She is capable as he, but when she labors, she gets less wages. Why? Because she wears skirts instead of trousers."13 The patriarchy continued to abuse and exploit women for several reasons, which is why " $\mathrm{t}]$ he woman, instead of being the household queen, told about in story books, is the servant, the mistress, and the slave of both husband and children. She loses her own individuality entirely, even her name she is not allowed to keep." ${ }^{14}$ When, early on in her political life, Goldman began to criticize the exploitation of women by marriage as an institutionalized form of control in the name of the patriarchy, it was not surprising that she made enemies, who would later establish her public image as a "dangerous individual."15 While this image stretched back to the assassination of US President William McKinley (1843-1901) and was intensified by a press campaign, ${ }^{16}$ Goldman was probably one of the most influential anarchists in the United States and one of the anarcha-feminists whose ideas about equality made her quite appealing for feminists in later times as well. ${ }^{17}$

As American scholar Blaine McKinley emphasized, “[a]s men and women whose aspirations contrasted with those of most Americans, the anarchists saw the contradictions and inequalities of modern America," 18 and Goldman expressed her criticism of these inequalities quite loudly and prominently. Like other anarchists, Goldman "offered a unique viewpoint on their times and experienced tensions that illuminated American society. Uncomfortable with the pre-

12 Frank Jacob, "Emma Goldmans Blick auf Bolschewismus, Faschismus und Nationalsozialismus: Eine anarchistische Perspektive auf den Totalitarismus der 1920er- und 1930er-Jahre," Zeitschrift für Geschichtswissenschaft 68, no. 10 (2019): 833-847.

13 Goldman, “What Is There in Anarchy for Woman?" 291.

14 Ibid.

15 Ferguson, "Discourses of Danger," 736.

16 Alex Kates Shulman, "Introduction," in Red Emma Speaks: Selected Writings and Speeches by Emma Goldman, ed. Alex Kates Shulman (New York: Vintage Books, 1972), 11-12.

17 Loretta Kensinger, "Radical Lessons: Thoughts on Emma Goldman, Chaos, Grief, and Political Violence Post-9/11/01,” Feminist Teacher 20, no. 1 (2009): 52-53.

18 Blaine McKinley, “'The Quagmires of Necessity': American Anarchists and Dilemmas of Vocation," American Quarterly 34, no. 5 (1982): 503. 
sent, they remained torn between the simpler past and the possible future."19 However, and regardless of the political demands of her own political movement, Goldman could also observe a kind of anarcho-sexism, which was often expressed by male comrades who demanded equality and freedom, but only for men. ${ }^{20}$ Or as Goldman herself worded it: "Even radials do not differ from the christians [sic]; they do not wish their wives to become radical; even they deem themselves necessary to her protection."21 For the female anarchist, it was important that women gained emancipation from exploitative marriage structures and thereby sexual emancipation as well to become an essential part of the anarchist revolution of the future. ${ }^{22}$ Donna M. Kowal, who studied Goldman's anarcha-feminist positions in great detail, highlights the feminist elements in her political agenda, as “Goldman's approach to anarchism emphasised the economic and psychosocial necessity of emancipating women, which she believed could only the accomplished through anarchism's ability to transcend artificial differences and class divisions between women and men." ${ }^{23}$ Regardless of such views, Goldman also struggled with her political demands as they rarely tallied with her own life, in which the anarchist, e.g. in her relationship with Ben Reitman, remained what feminist Goldman biographer Alice Wexler called a "slave to sexual passion," ${ }^{24}$ seemingly unable to live up to her own ideals. $^{25}$

The present chapter is nevertheless interested in Goldman's views on marriage and sexual liberation. While the former was considered to be an instrument of suppression, the latter, for the anarchist Goldman, meant a form of liberation of the female body and the female mind. After a short elaboration of Goldman's anarcha-feminist identity, this chapter will consequently take a closer look at her discourses about marriage and her ideas about the sexual liberation of women. It will thereby show that her thoughts about emancipation were quite ahead of her time and that freedom was one of the values Goldman would only consider and

19 Ibid., 503-504.

20 Lucy Nicholas, "Gender and Sexuality," in The Palgrave Handbook of Anarchism, eds. Carl Levy and Matthew S. Adams (Cham: Palgrave Macmillan, 2019), 605.

21 Emma Goldman, "The New Woman," Free Society, February 13, 1898, 2, in Emma Goldman: A Documentary History of the American Years, vol. 1: Made for America, 1890-1901, eds. Candace Falk et al. (Urbana/Chicago, IL: University of Illinois Press, 2008), 322.

22 On Goldman's concept of an anarchist revolution, see Frank Jacob, “An Anarchist Revolution? Emma Goldman as an Intellectual Revolutionary,” Journal for the Study of Radicalism 15, no. 2 (2021), forthcoming.

23 Kowal, "Anarcha-Feminism," 274.

24 Wexler, Emma Goldman, 160.

25 Ferguson, "Gender and Genre," 735. 
accept in its most total form and if applied or available for all, men and women alike.

\title{
Emma Goldman: An Early Anarcha-Feminist
}

Goldman was active in numerous ways: she was an anarchist revolutionary, but she also fought for the right of abortion, she was an anarchist, but also a protofeminist. It is consequently appropriate consider one of her many different identities to be an anarcha-feminist one. ${ }^{26}$ Kowal emphasized that "anarcha-feminists presented an alternative model of womanhood” and that

\begin{abstract}
Within the anarchist political and intellectual milieu of the late nineteenth and early twentieth centuries, anarcha-feminism emerged as a distinct, albeit loosely formed, 'school of thought' that was reflected in the transnational activism of anarchist women ... [who] tended to interpret the anarchist critique of authority through the lens of their experiences as women, especially constraints resulting from sexual double standards and the gendered division of labor. ${ }^{27}$
\end{abstract}

The label "anarcha-feminist" as such was, however, not used by these women themselves but later introduced by researchers who studied their cases. ${ }^{28}$ It must nevertheless be seen as a consequence of the exclusion of women from political and public affairs, something that was not only criticized by female anarchists during the late 19th and early 20th centuries. ${ }^{29}$ The stand against discrimination and for full emancipation nevertheless, as in other national contexts as well, led to a struggle within the predominantly male political movements, be they anarchist or socialist. ${ }^{30}$

26 For a discussion of Goldman's different identities see Jacob, Emma Goldman and the Russian Revolution, 17-46 and the forthcoming Frank Jacob, Emma Goldman: Die Identitäten einer Anarchistin (Berlin: Hentrich \& Hentrich, 2021).

27 Kowal, “Anarcha-Feminism," 265.

28 Ibid., 266.

29 For a different example in the US context see Jowan A. Mohammed, "Mary Hunter Austin und die Forderungen nach einer Vernderung der Geschlechterrollen in den USA, 1914-1918,” in Geschlecht und Klassenkampf: Die "Frauenfrage" aus deutscher und internationaler Perspektive im 19. und 20. Jahrhundert, eds. Vincent Streichhahn and Frank Jacob (Berlin: Metropol, 2020), $222-239$.

30 For a recent analysis of this question within German social democracy, see Vincent Streichhahn, "Zur 'Frauenfrage' und Sozialdemokratie im deutschen Kaiserreich Zwischen Antifeminismus und Emanzipation," in Geschlecht und Klassenkampf: Die "Frauenfrage" aus deutscher und 
At the same time, "anarcha-feminist thought is not uniform" ${ }^{31}$ but as diverse as anarchism itself. ${ }^{32}$ Although the anarcha-feminists were also quite different with regard to their upbringing, social background, and the arguments they used, they were unified by "[r]ejecting compulsory marriage and motherhood, [and] they sought to enact their unconventional ideas of autonomous living and sexual agency."33 Their aim was consequently to change the existent social order and gender norms alike, and it is no surprise that the "early anarchist feminist focus was on the rejection of state-sanctioned marriage but also on the imagination and prefiguration of alternative, non-dominative gender and sexual relations such as ideals of free love." ${ }^{34}$ This does not, however, mean that there was no struggle among the anarcha-feminists, who would criticize each other. Voltairine de Cleyre (1866-1912), ${ }^{35}$ for example, criticized Goldman for living off and not for the anarchist movement, ${ }^{36}$ although the latter used hardly any money she made for her personal life, instead reinvesting most of her income from lectures into publications of friends and herself to support the anarchist movement further. ${ }^{37}$

New York, where Goldman would start her activities as an anarchist speaker, was more than a metropolis of the United States in the late 19th century; it was a melting pot for anarchist immigrant communities from Germany, Italy, Czarist Russia, and other places, ${ }^{38}$ whose ideas about "abolitionism, free thought, and the labor movement" were exchanged as they "were troubled by the economic inequalities, centralized power, and mass society they saw arising at the expense

internationaler Perspektive im 19. und 20. Jahrhundert, eds. Vincent Streichhahn and Frank Jacob (Berlin: Metropol, 2020), 48-77.

31 Kowal, “Anarcha-Feminism,” 267.

32 Benjamin Franks, Nathan Jun and Leonard Williams, eds., Anarchism: A Conceptual Approach (New York/London: Routledge, 2018); Sean Sheehan, Anarchism (London: Reaktion, 2003).

33 Kowal, "Anarcha-Feminism," 275.

34 Nicholas, "Gender and Sexuality," 606-607.

35 Eugenia C. DeLamotte, Gates of Freedom: Voltairine de Cleyre and the Revolution of the Mind (Ann Arbor, MI: University of Michigan Press, 2004); Sharon Presley and Crispin Sartwell, Exquisite Rebel: The Essays of Voltairine De Cleyre-Anarchist, Feminist, Genius (Albany, NY: State University of New York Press, 2005).

36 Voltairine de Cleyre to Saul Yanovsky, October 18, 1910, Ishill Papers, Joseph Ishill Papers, Houghton Library, Harvard University; Voltairine de Cleyre to Joseph Cohen, October 26, 1910, Joseph Cohen Papers, Bund Archives of the Jewish Labor Movement, YIVO Archives, New York. Both letters are cited in McKinley, "The Quagmires," 519.

37 Ibid., 512 and 519-520.

38 Kenyon Zimmer, Immigrants against the State: Yiddish and Italian Anarchism in America (Urbana, IL: Illinois University Press, 2015). 
of local self-sufficiency and personal initiative." ${ }^{39}$ Especially for Jewish immigrants, America did not fulfill the expectations for a better life than the one they had left behind in Central and Eastern Europe, a region French historians Alain Brossat and Sylvia Klingberg referred to as "revolutionary Yiddishland" 40 and which Goldman had also intended to leave behind for a better life with her sister Helena in America. ${ }^{41}$ She described her own transformation in relation to the changing of her dreams, especially with regard to the harsh US experience later, as follows:

\begin{abstract}
Naturally, life presents itself in different forms to different ages. Between the age of eight and twelve I dreamed of becoming a Judith. I longed to avenge the sufferings of my people, the Jews, to cut off the head of their Holofernos. When I was fourteen I wanted to study medicine, so as to be able to help my fellow-beings. When I was fifteen I suffered from unrequited love, and I wanted to commit suicide in a romantic way by drinking a lot of vinegar. I thought that would make me look ethereal and interesting, very pale and poetic when in my grave, but at sixteen I decided on a more exalted death. I wanted to dance myself to death. ... Then came America, with its huge factories, the pedalling of a machine for ten hours a day at two dollars fifty a week. ${ }^{42}$
\end{abstract}

For Jewish immigrants like Goldman, the United States represented the same misery they had tried to escape, and there was almost no difference with regard to poverty and sorrow. ${ }^{43}$ When the female anarchist compared the lives of the Jewish immigrants in the "New World" with their former one in Europe, there was nothing much to cheer about: "There [in Russa] he must work like a galley slave whether he will or no. Here he is free-free to starve, free to be robbed and swindled on every hand. But the moment he seeks to organize labor, or assert his

39 McKinley, “The Quagmires,” 504.

40 Alain Brossat and Sylvia Klingberg, Revolutionary Yiddishland: A History of Jewish Radicalism, trans. David Fernbach (London/New York: Verso, 2016). On the Jewish radical community in New York, also see Tony Michels, A Fire in Their Hearts: Yiddish Socialists in New York (Cambridge, MA/London: Harvard University Press, 2005); Frank Jacob, "Radical Trinity. Anarchist, Jew, or New Yorker?” in Jewish Radicalisms: Historical Perspectives on a Phenomenon of Global Modernity, eds. Frank Jacob and Sebastian Kunze (Berlin: De Gruyter Oldenbourg, 2019), 153180.

41 Kowal remarks that Goldman "immigrated to the United States in 1886 to fell a restrictive Orthodox life.” Kowal, "Anarcha-Feminism,” 273.

42 Goldman, "An Anarchist Looks at Life," 4-5.

43 "A Woman Anarchist," Pittsburgh Leader, November 22, 1896, in Emma Goldman: A Documentary History of the American Years, vol. 1: Made for America, 1890-1901, eds. Candace Falk et al. (Urbana/Chicago, IL: University of Illinois Press, 2008), 243-244. 
rights or strike for the defense of his dearest interests he is no longer free, but is apprehended and thrown in prison." 44

What must be understood here is that Goldman turned into an anarchist in the United States, meaning that her radical ideas and her identity as an anarchist were American in origin. When she was a young female in Russia, she dreamed of the land of opportunities: "There was still America, the gloriously free land where one is free to develop and to grow. The reception given immigrants even to-day is enough to outrage one's sensibilities, but forty years ago the treatment meted out of the people who pilgrimmed to America as to the promised land was so utterly appalling that it helped to deepen my hatred of man's inhumanity to man." 45 After a failed marriage ${ }^{46}$ and her own "inauguration into the economic life in the States," due to which she had to work hard to make ends meet at the factory, she experienced "harsh treatment, [when the workers were] driven like slaves." And, almost natually, her "whole being rebelled" 47 against this form of unjust exploitation, as it was showing Goldman "how utterly corrupt and unscrupulous are those who grow rich on the toil of others. It also increased my contempts for the system which grinds human beings into gold dust." ${ }^{48}$ In addition to this event, it was the Haymarket Trage$\mathrm{dy}^{49}$-when anarchists were tried and executed based on suspicions but without any proof of being involved in a bomb attack on the police in Chicago in 1886that "gave [her] feeling, form, and reality." 50 Goldman later claimed that "[t]he colossal crime of the State of Illinois, the bloodthirstiness of the press, the madness from [the] pulpit, and platform, the whole brutal business made a conscious Anarchist of me"51 and that "[t]he death of those Chicago martyrs was my spiritual birth: their ideal became the motive of my entire life." 52 All in all, these events and experiences would turn the young immigrant into an anarchist, and after her deportation from the US in December 1919, she would continue to argue that "the exploitation of the masses is nowh[e]re quite so intensive as in

\footnotetext{
44 Ibid., 244.

45 Emma Goldman, "Why I am an Anarchist,” n.d., EGP-IISH, No. 191, 2-3.

46 Deportation Hearings of Alexander Berkman and Emma Goldman, Stenographer's Minutes, December 8, 1919, Alexander Berkman Papers, Tamiment Library and Robert F. Wagner Labor Archives, New York University, New York City, NY, United States of America (henceforth ABPTAM), TAM.067, Box 1, Folder 3, 28 and 30.

47 Ibid., 3.

48 Ibid.

49 Paul Avrich, The Haymarket Tragedy (Princeton, NJ: Princeton University Press, 1984).

50 Goldman, "Why I am an Anarchist," 3.

51 Ibid.

52 Goldman, "An Anarchist Looks at Life," 5.
} 
the United States." 53 For the anarchist, it was obvious that the people there needed to embrace anarchist ideas to overcome the existent systemic problems because "[p]ower over others corrupts, brutalises and destroys the sense of proportion. It makes for conflict, strife and disintegration." 54

In contrast to many unknown anarchists ${ }^{55}$ who were not as popular as Goldman or her lifelong companion Alexander Berkman (1870-1936), she could later afford to leave this hard experience of being exploited behind her to focus on her anarchist works as a publisher of the journal Mother Earth. At the same time, however, Goldman would be perceived as a dangerous woman, as the "dominant personality among American anarchists," ${ }^{56}$ and as a threat to the existent political and social order. When Berkman attempted to assassinate Henry Clay Frick (1849-1919), "the man responsible for the violence against striking workers at the Carnegie steel mills in Homestead, Pennsylvania"57 in 1892, Goldman, who in general did not favor the use of violence, defended Berkman's decision, because "it was his belief that if the capitalists used Winchester rifles and bayonets on workingmen they should be answered with dynamite."58 Berkman was nevertheless sentenced to spend 22 years in prison, but was released after 14 in $1906 .{ }^{59}$ The moment he was able to leave prison, as Berkman described it,

was a moment of supreme joy when I felt the heavy chains, that had bound me so long, give way with the final clang of the iron doors behind me and I suddenly found myself transported, as it were, from the dreary night of my prison-existence into the warm sunshine of the living day; and then, as I breathed the free air of the beautiful May morning-my first breath of freedom in fourteen years-it seemed to me as if a beautiful nature had waved her magic wand and marshalled her most alluring charms to welcome me into the world again. ${ }^{60}$

53 Emma Goldman, “Good and Evil points in the Makeup of America,” n.d. [1924], EGP-IISH, No. $189,3$.

54 Emma Goldman, “Anarchism and What It Really Stands For," n.d., EGP-IISH, No. 191, $5^{1 / 2}$. 55 On the different types of anarchists according to four categories related to their income and living conditions, see McKinley, "The Quagmires,” 505.

56 Ibid., 516.

57 Ferguson, "Discourses of Danger," 744.

58 “Goldman's Cry Against Society," Pittsburgh Post, November 27, 1896, in Emma Goldman: A Documentary History of the American Years, vol. 1: Made for America, 1890-1901, eds. Candace Falk et al. (Urbana/Chicago, IL: University of Illinois Press, 2008), 249.

59 Alexander Berkman, Prison Memoirs of an Anarchist (New York: Mother Earth Publishing, 1912).

60 Alexander Berkman, “A Greeting,” Mother Earth 1, no. 4 (1906), accessed October 17, 2019, http://dwardmac.pitzer.edu/Anarchist_Archives/goldman/ME/mev1n4.html. 
Regardless of his time spent in prison, Berkman immediately joined the anarchist movement again and supported Goldman in her work for Mother Earth. The latter took the release of her friend as a reason to sum up the causes and events of 1892 for their readers:

\begin{abstract}
In looking over the events of 1892 and the causes that led up to the act of Alexander Berkman, one beholds Mammon seated upon a throne built of human bodies, without a trace of sympathy on its Gorgon brow for the creatures it controls. These victims bent and worn, with the reflex of the glow of the steel and iron furnaces in their haggard faces, carry their sacrificial offerings to the ever-insatiable monster, capitalism. In its greed, however, it reaches out for more; it neither sees the gleam of hate in the sunken eyes of its slaves, nor can it hear the murmurs of discontent and rebellion coming forth from their heaving breasts. Yet, discontent continues until one day it raises its mighty voice and demands to be heard: Human conditions! higher pay! ${ }^{61}$
\end{abstract}

Goldman intended to use Mother Earth to awaken the political consciousness of the readers, who might get in contact with anarchist ideas for the first time. And it was her most important project, once she had decided to fully invest all her energy and financial capacity in this journal. In 1905, a year before Mother Earth was founded, Goldman had "borrowed money to open a facial and scalp massage parlor for middle-class, 'professional' women." ${ }^{\text {2 }}$ The parlor went well, and the anarchist Goldman made a profit for the first time. Maybe this was one reason for her to give up this opportunity when she was able to establish her own journal the next year. Finally, "[b]y earning her livelihood from the movement itself, she avoided the problems of a double life which had troubled her." ${ }^{33}$ Although Goldman herself was never truly the "modern woman" she considered herself to be, Mother Earth was supposed to act as a platform of all kinds of anarchist ideas and to provide a possibility for the exchange of different views on society. ${ }^{64}$ Goldman and Berkman themselves later formulated the raison d'être of Mother Earth as follows:

As to the original raison d'etre of MOTHER EARTH, it was, first of all, to create a medium for the free expression of our ideas, a medium bold, defiant, and unafraid. That she has proved to the fullest, for neither friend nor foe has been able to gag her. Secondly, MOTHER EARTH was to serve as a gathering point, as it were, for those, who, struggling to free themselves from the absurdities of the Old, had not yet reached firm footing Suspended between heav-

61 E.[mma] G.[oldman], “Alexander Berkman,” Mother Earth 1, no. 3 (1906), accessed October 17, 2019, http://www.gutenberg.org/files/27262/27262-h/27262-h.htm\#Page_22.

62 McKinley, “The Quagmires,” 517.

63 Ibid.

64 Ferguson, "Gender and Genre," 743-744. 
en and hell, they have found in MOTHER EARTH the anchor of life. Thirdly, to infuse new blood into Anarchism, which-in America-had then been running at low ebb for quite some time. All these purposes, it may be said impartially, the magazine has served faithfully and well..$^{65}$

Goldman used her journal to confront existent gender and social norms, as well as for political criticism of the US government. Referencing Michel Foucault, Kathy E. Ferguson called her "bold confrontations with authorities" acts of "anarchist parrhesia, fearless speech, a relentless truth-telling practice that risked her own security in pursuit of her 'beautiful ideal."”66

One of the other aspects Goldman reflected upon in Mother Earth was the "Tragedy of Women's Emancipation." ${ }^{67}$ She wanted to point out why women should have the same liberties as men and why equality was a precondition for true emancipation. Goldman emphasized that "[p]eace and harmony between the sexes, and individuals does not necessarily depend on a superficial equalization of human beings; nor does it call for the elimination of individual traits or peculiarities. The problem that confronts us, to-day, and which the nearest future is to solve, is how to be oneself, and yet in oneness with others, to feel deeply with all human beings and still retain one's own innate qualities." ${ }^{\text {68 }}$ The anarchist Goldman demanded that female emancipation should not be considered as a hostile project for society, because "man and woman can meet without antagonism and opposition. The motto should, not be forgive one another; it should be, understand one another." 69

It was emancipation that was supposed to "make it possible for [women] to be human in the truest sense," but to achieve it, "all artificial barriers should be broken and the road towards greater freedom cleared of every trace of centuries of submission and slavery."70 The tragedy with regard to previous emancipation attempts, however, was clearly visible for Goldman, as

65 Emma Goldman and Alexander Berkman, "Our Sixth Birthday,” Mother Earth 6, no. 1 (1911), accessed February 26, 2020, http://dwardmac.pitzer.edu/Anarchist_Archives/goldman/ ME/mev6n1.html.

66 Ferguson, "Discourses of Danger," 738. For Foucault's text see Michel Foucault, Fearless Speech, ed. Joseph Pearson (Los Angeles: Semiotext(e), 2001), 19.

67 Emma Goldman, “Tragedy of Women's Emancipation,” Mother Earth 1, no. 1 (1906): 9-17, http://dwardmac.pitzer.edu/Anarchist_Archives/goldman/ME/mev1n1.html\#tra.

68 Ibid.

69 Ibid. My emphasis.

70 Ibid. 
the results so far achieved have isolated woman and have robbed her of the fountain springs of that happiness which is so essential to her. Merely external emancipation has made of the modern woman an artificial being ...; anything except the forms which would be reached by the expression of their own inner qualities. Such artificially grown plants of the female sex are to be found in large numbers, especially in the so-called intellectual sphere of our life. ${ }^{71}$

Consequently, Goldman argued that "the emancipation of woman, as interpreted and practically applied to-day, has failed to reach that great end [i.e. true freedom and equality]. Now, woman is confronted with the necessity of emancipation from emancipation, if she really desires to be free. This may sound paradoxical, but is, nevertheless, only too true."72 While "economic equality" could have been achieved in some professions, "[v]ery few [women] ever succeed, for it is a fact that women doctors, lawyers, architects and engineers are neither met with the same confidence, nor do they receive the same remuneration., ${ }^{73}$

The achievements of emancipation were consequently not good enough to have fully freed women from the suppression of the patriarchy, and Goldman would therefore criticize it by calling the previous emancipation a tragedy for women:

The narrowness of the existing conception of woman's independence and emancipation; the dread of love for a man who is not her social equal; the fear that love will rob her of her freedom and independence, the horror that love or the joy of motherhood will only hinder her in the full exercise of her profession-all these together make of the emancipated modern woman a compulsory vestal, before whom life, with its great clarifying sorrows and its deep, entrancing joys, rolls on without touching or gripping her soul. ${ }^{74}$

In a letter to Berkman on 4 September 1925, i.e. almost 20 years later, Goldman would again emphasize the "tragedy of all of us modern women," which for her was based on the "fact that we are removed only by a very short period from our traditions, the traditions of being loved, cared for, protected, secured, and above all, the time when women could look forward to an old age of children, a home and someone to brighten their lives." For Goldman, it was clear that "[t]he modern woman cannot be the wife and mother in the old sense, and the new medium has not yet been devised, I mean the way of being wife, mother, friend and yet

71 Ibid.

72 Ibid.

73 Ibid.

74 Ibid. 
retain one's complete freedom. Will it ever?"75 Two aspects were essential for Goldman's view that emancipation had failed, namely the continuation of traditional means of patriarchic control, i.e. marriage, and the lack of sexual freedom for women. These two aspects shall now be taken into closer consideration.

\section{Against Marriage}

The continuation of the traditional views on marriage was, from Goldman's point of view, based on "the twin fantasies of protection and social mobility through [it]." 76 Women should rather be revolutionary and contest the contemporary perspective on marriage. Although such demands would also arouse criticism from her male anarchist comrades, Goldman did not back away from her demand that a true emancipation of women also needed to contest the existent idea of marriage. As Clare Hemmings, professor of feminist theory at the London School of Economics, worded it, "[f]or Goldman, marriage is the basis of private property and the particular oppression of women."77 Marriage had turned out to be often nothing more than "an economic arrangement, an insurance pact"78 for women, who were exploited in their marriage as they were as workers in the factories. Women would be dependent on men for the rest of their lives and doomed to live a life as parasite-like creatures, unable to achieve true freedom and equality as individuals. ${ }^{79}$

In an article for Firebrand in 1897, Goldman expressed her views on marriage quite outspokenly: "From its very birth, up to our present day, men and women groan under the iron yoke of our marriage institution, and there seems to be no relief, no way out of it."80 The relationship between women and men had been diminished to a capitalist form of exploitation because, as Goldman continued in her evaluation, "marriage relations, are the foundation of private property, ergo,

75 Letter to Alexander Berkman, September 4, 1925, in Nowhere at Home: Letters from Exile of Emma Goldman and Alexander Berkman, eds. Richard Drinnon and Anna Maria Drinnon (New York: Schocken Books, 1975), 130 -133, cited in Ferguson, "Gender and Genre," 736.

76 Clare Hemmings, "In the Mood for Revolution: Emma Goldman’s Passion,” New Literary History 43, no. 3 (2012): 527.

77 Clare Hemmings, “Sexual Freedom and the Promise of Revolution: Emma Goldman's Passion,” Feminist Review 106 (2014): 49.

78 Emma Goldman, Marriage and Love (New York: Mother Earth Publishing, 1911), 4.

79 Ibid.

80 Emma Goldman, "Marriage," Firebrand, July 18, 1897, 2, in Emma Goldman: A Documentary History of the American Years, vol. 1: Made for America, 1890-1901, eds. Candace Falk et al. (Urbana/Chicago, IL: University of Illinois Press, 2008), 269. 
the foundation of our cruel and inhuman system." ${ }^{81}$ Goldman considered marriage to be a tool of patriarchic control as "[i]t always gives the man the right and power over his wife, not only over her body, but also over her actions, her wishes; in fact, over her whole life." ${ }^{22}$ The relationship between men and women was not equal but privileged for the former, who could exploit the latter as mother and housewife. With regard to the two sexes, it was "[p]ublic opinion [that] separate[d] their rights and duties, their honor and dishonor very strictly from each other." ${ }^{83}$ At the same time, women were not granted their individual freedom, especially with regard to sex: "The subject of sex is a sealed book to the girl, because she has been given to understand that it is impure, immoral and indecent to even mention the sex question." ${ }^{84}$ Women who were married were kept sexually uneducated on purpose to limit them in their liberation as females who could feel sexual pleasure as well. In addition to this form of exploitation of their bodies, women were also exploited in marriage because such relationships could hardly be called equal:

Both, the man and the girl, marry for the same purpose, with the only exception that the
man is not expected to give up his individuality, his name, his independence, whereas
the girl has to sell herself, body and soul, for the pleasure of being someone's wife;
hence they do not stand on equal terms, and where, there is no equality there can be no
harmony. The consequence is that shortly after the first few months, or to make all allow-
ance possible, after the first year, both come to the conclusion that marriage is a failure. ${ }^{85}$

It was therefore obvious for Goldman early on that marriage was an essential part of the systemic exploitation of women. She therefore could not believe that "many emancipated women prefer marriage with all its deficiencies to the narrowness of an unmarried life; narrow and unendurable because of the chains of moral and social prejudice that cramp and bind her nature." ${ }^{86}$ The tragedy for Goldman was based on the fact that many women did not understand the full "meaning of emancipation. They thought that all that was needed was independence from external tyrannies; the internal tyrants, far more harmful to life and growth, such as ethical and social conventions, were left to take care of themselves; and they have taken care of themselves." ${ }^{87}$ Full emancipation could con-

81 Ibid.

82 Ibid.

83 Ibid., 270.

84 Ibid.

85 Ibid., 271.

86 Goldman, "Tragedy of Women's Emancipation.”

87 Ibid. 
sequently not be achieved as long as women continued to live according to oldfashioned and outdated traditions like marriage that would force them to give up their individual freedom. Goldman therefore argued: "Indeed if the partial emancipation is to become a complete and true emancipation of woman it will have to do away with the ridiculous notion that to be loved, to be sweetheart and mother, is synonomous [sic] with being slave or subordinate. It will have to do away with the absurd notion of the dualism of the sexes, or that man and woman represent two antagonistic worlds." 88 Only together were women and men able to become equal, and only together and without any hierarchy could both be truly free. Kathy E. Ferguson summed up this vision of the US anarchist as follows:

For Goldman, love between two people should create an intensified microcosm of the more general relation between individuals and the community in a liberated society. She envisioned anarchist love as creating bonds between free individuals that would enhance rather than confine each person. Similarly, she envisioned an anarchist society as a voluntary community of free, self-directing individuals, where individual growth and empowerment are nurtured through collective life. ${ }^{89}$

Regardless of her many later political endeavors, Goldman never gave up the hope for an honest and full emancipation of women, but in her later years she would continue to lecture about "The Tragedy of the Modern Woman."90

Goldman outlined that women had achieved political rights in the past, but the course of history had shown "that woman in politics is by no means better than man and her right of suffrage has helped her as little as it did most men to overcome outworn political, social, or moral values." ${ }^{91}$ In particular, since women had been unable to leave the limiting forces of tradition behind, they had been unable to fully free themselves. It was women who still kept worshipping men to a level of self-denial: "When she [the modern woman] loves the man, she turns him into a god and surrounds him with a sacred hallow. In her blind idolization she falls to see that her deity is but human, all too human. The poor fool knows only too well that he is far from the hero imagined by his mother, wife, daughter, or mistress." 92 Yet instead of freeing the woman, the modern man would exploit her in multiple ways. Goldman also accused the modern women for their blind obedience, as they "were the most ardent support-

88 Ibid.

89 Ferguson, “Gender and Genre," 751.

90 Emma Goldman, “The Tragedy of the Modern Woman,” n.d., EGP-IISH, No. 266.

91 Ibid., 1.

92 Ibid., 3. 
ers of war to the extent of using their sex charms and persuasion to drive the youth of the land into the trenches and death."93 And regardless of the political rights the suffragette movement had been able to secure in the past, "woman's political equality with man has contributed precious little to her inner emancipation." ${ }^{94}$ At the same time, she continued to point out that the exploitation of women was not limited to their private life but also with regard to their working conditions: "As to the great mass of working girls and women, how much independence is gained if the narrowness and lack of freedom of the home is exchanged for the narrowness and lack of freedom of the factory, sweat-shop, department store, or office?"95 The tragedy of the modern woman was consequently an exploitation that existed in a twofold way and could only be overcome by a political and social change.

The working conditions of poor women made it relatively unsurprising "that hundreds of girls are so willing to accept the first offer of marriage, sick and tired of their 'independence'," 96 although this decision would only lead to another form of exploitation. This "so-called independence which leads only to earning the merest subsistence is not so enticing, not so ideal, that one could expect woman to sacrifice everything for it. Our highly praised independence is, after all, but a slow process of dulling and stifling woman's nature, her low need, and her mother instinct." ${ }^{97}$ The possibility to live free and independent was eventually given up due to the circumstances of being economically exploited in a capitalist system. The fact that representatives of the women's movement, especially the suffragettes, accepted the continuation of this system in exchange for a small share of political power was another of the reasons Goldman identified with regard to the tragedy of the modern woman: "Every movement that aims at the destruction of existing institutions and the replacement thereof with something more advanced, more perfect had followers who in theory stand for the most radical ideas, but who, nevertheless, in their every-day practice, are like the average philistine, feigning respectability and clamoring for the good opinion of their opponents. The suffragist and feminist movements made no exception."98

A true and full emancipation, however, needed more than just political rights. It needed freedom and equality, the two pillars of Goldman's interpreta-

\footnotetext{
93 Ibid., 7.

94 Ibid., $8^{1 / 2}$.

95 Ibid., $13^{1 / 2}$.

96 Ibid.

97 Ibid., 14.

98 Ibid., $18^{1 / 2}$.
} 
tion of anarchism. The modern man, as she argued, "still wants woman as his housekeeper and caretaker of his home and his children. But he wants her in modern clothes." 99 The modern woman, on the other hand, "lacks courage to be inwardly free. Even with herself she is not frank." ${ }^{100}$ Women in general did still accept the existent social norms and were therefore "still swayed by sentimental considerations. [The modern woman] still has too many gods. The result is lack of concentration and sticktoitiveness so essential to every goal one wishes to reach."101 For Goldman, it was consequently foolish women who would pave the way for men while they denied their own freedom: "woman has not yet learned to march to victory regardless of the defeat of those in her way. Hence she has not reached greatness." ${ }^{\text {"102 }}$ What kept women from fully emancipating was the fear of losing men's interest in them because, as Goldman continued in her argument, "the higher the mental development of [the modern] woman, the less possible it is for her to meet a congenial mate who will see in her, not only sex, but also the human being, the friend, the comrade and strong individuality, who cannot and ought not lose a single trait of her character." ${ }^{103}$ If women were unable to be loved for their individuality but solely because they could be exploited, they would never be free, and "[i]f love does not know how to give and take without restrictions, it is not love, but a transaction that never fails to lay stress on a plus and a minus."104 The modern woman, who "is in need of unhampered growth out of old traditions and habits"105 therefore must resist traditional role models and disobey social expectations like marriage. For Goldman, it was instead "necessary that women learn to accept themselves and to value themselves as beings possessing a worth at least equal to that of the other sex, instead of unthinkingly accepting standards based on masculine psychology." ${ }^{106}$ All in all, it was and still is important for a successful emancipation to "do away with the absurd notion of the conflict of the sexes, or that man and woman represent two antagonistic worlds." 107 These considerations are still important today and, as emphasized before, "[o]nly if the microcosms of romantic love and interpersonal relationships are freed from all forms of male

99 Ibid., 22.

100 Ibid., 29.

101 Ibid., 30.

102 Ibid., 31.

103 Ibid., 33.

104 Ibid., $36^{1 / 2}$.

105 Ibid., 39.

106 Ibid., 40.

107 Ibid., 41. 
domination and dominance could a better and freer society be created." ${ }^{108}$ To achieve this aim, Goldman, however, did not only want to increase awareness of the problems related to marriage as a traditional tool of patriarchic control over women; she also wanted women to gain their freedom with regard to their own sexuality and the possibilities to experience sexual pleasure.

\section{For Sexual Liberation}

Goldman was familiar with the works of German sexologist Magnus Hirschfeld $(1868-1935),{ }^{109}$ and she "admired the brave struggle [Hirschfeld] ha[d] made for the rights of people who, by their very nature, can not find sex expression in what is commonly called 'the normal way'." 110 Goldman was interested in sexuality, as she considered it an important part of women's liberation. Like the American poet Walt Whitman (1819-1892), the anarchist highlighted "the beauty and wholesomeness of sex ... freed from the rags and tatters of hypocrisy."111 Goldman's "insistence that women's experiences and sexual freedom must be incorporated into the heart of any sustainable revolution" ${ }^{\text {"112 }}$ consequently does not surprise, as her appeal to the feminists of the 1960s and 1970s seemed to be quite natural, given this element of the anarchist's revolutionary considerations. Sexual liberation would allow women to break out of the social system that kept them hostages and exploited them physically and mentally. Only a free form of sexual self-expression would allow women equality with men, freeing their identities from the mother roles they were supposed to imitate in their lives after having been forced into marriage by social pressure. Goldman therefore, as Clare Hemmings has pointed out, "consistently situate[s] sexuality in a broad political context of the sexual division of labour, the institutions of marriage and the church, consumerism, patriotism and productive (as well as repro-

108 Jacob, “Anarchismus, Ehe und Sex,” 216.

109 For Hirschfeld's life and work, see Manfred Herzer, Magnus Hirschfeld und seine Zeit (Berlin: De Gruyter, 2017).

110 Emma Goldman, “A Refutation Addressed to Dr. Magnus Hirschfeld,” Berlin 1923, EGPIISH, No. 208, 1. Some years later, Goldman would also meet Hirschfeld in Paris. Magnus Hirschfeld to Emma Goldman, Paris, November 24, 1933, EGP-IISH, No. 98.

111 Emma Goldman, "Walt Whitman" (1916), in The Emma Goldman Papers: A Microfilm Edition, ed. Candace Falk with Ronald J. Zborayetal, reel 54 (Alexandria, VA: Chadwyck-Healey, 1990), 2, cited in Ferguson, "Gender and Genre," 747.

112 Hemmings, "Sexual Freedom," 44. 
ductive) labour, [and] she frames sexual freedom as both the basis of new relationships between men and women and as a model for a new political future."113

To achieve freedom and equality, the basis and aim for Goldman's anarchist vision was important for sexual identity as well, because sexuality had to be separated from any form of capitalist exploitation to allow for a better, i.e. freer, life. While left intellectuals had been "suspicious of attention to desire and pleasure,"114 Goldman embraced these aspects and made them an essential part of her political agenda. Beyond their daughter- or mother-identity, women should consider their sexuality and sexual pleasure as a way to express themselves as females, who should naturally not be restricted by traditional roles with regard to their desire. If sexuality continued to be considered as something unrelated to the suppression of women, it would not allow women to break the co-constitution of sexuality and labor and its impact on different ways of exploitation. ${ }^{115}$ Sexual freedom was a precondition for every passionate revolutionary, and a famous episode from Goldman's life emphasizes that she would not accept being part of an unpassionate liberation movement:

At the dances I was one of the most untiring and gayest. One evening a cousin of Sasha [Alexander Berkman], a young boy, took me aside. With a grave face, as if he were about to announce the death of a dear comrade, he whispered to me that it did not behoove an agitator to dance. Certainly not with such reckless abandon, anyway. It was undignified for one who was on the way to become a force in the anarchist movement. My frivolity would only hurt the Cause. I grew furious at the impudent interference of the boy. I told him to mind his own business, I was tired of having the Cause constantly thrown into my face. I did not believe that a Cause which stood for a beautiful ideal, for anarchism, for release and freedom from conventions and prejudice, should demand the denial of life and joy. I insisted that our Cause could not expect me to become a nun and that the movement should not be turned into a cloister. If it meant that, I did not want it. "I want freedom, the right to self-expression, everybody's right to beautiful, radiant things." Anarchism meant that to me, and I would live it in spite of the whole world-prisons, persecution, everything. Yes, even in spite of the condemnation of my own closest comrades I would live my beautiful ideal. ${ }^{116}$

113 Ibid.

114 Lisa Rofel, “Queer Positions, Queerying Asian Studies,” Positions 20, no. 1 (2012): 185, cited in ibid., 46.

115 For a detailed discussion of this interrelationship, see Emma Goldman, The White Slave Traffic (New York: Mother Earth Publishing, 1909).

116 Emma Goldman, Living My Life (New York: Knopf, 1931), accessed December 17, 2018, https://www.theanarchistlibrary.org/library/emma-goldman-living-my-life, ch. 5. 
This call for freedom included sexual freedom, as the life of women was one determined by "sorrow, misery [and] humiliation"117 in relation to their sex. Hemmings emphasized how Goldman interpreted the co-dependency between sexuality and capitalist exploitation as follows:

Goldman locates the economy of women's sexuality firmly within the means of production and the exploitation of surplus labour. Women are not only commodities themselves, but also producers of the next generation of exploitable labour, within the twin evils of capitalism and militarism. Not only is women's experience of sex and love one of ignorant misery, her reproductive labour is bound as to what President Roosevelt saw as a national duty to provide offspring for the nation. ${ }^{118}$

The capitalist exploitation of women made Goldman also realize that birth control was a form of empowerment for women, who could decide on their own when and how to have children, without dooming the next generation to become a cog in the machine of the overall capitalist exploitation mechanism. ${ }^{119}$ The revolutionary transformation of society consequently needed a transformation of the idea of marriage, and related to this a reconsideration of female sexuality, especially by women themselves. She was not the only left intellectual who consequently considered the orgasm to be an experience of liberation. ${ }^{120}$ The sexual revolution Goldman envisioned would have ended the inequality between men and women and instead would pave the way to a unification of the sexes in the struggle against capitalism and for a better future for all.

For Goldman, sex was "woven into every fabric of human life and lays its finger on every custom. To the debit side of the sex account we must charge many silly stupidities and some of the foulest injustices which go to make the thing we call human culture the amazing and variegated mosaic that it is." ${ }^{121}$ She nevertheless demanded "the free sane acceptation of the human body, in all its faculties" because this acceptance presented "the master-key to the art of the future." 122 In contrast to men, women still suffered from all kinds of lim-

117 Goldman, "Marriage.”

118 Hemmings, "Sexual Freedom," 50.

119 Emma Goldman, “The Social Aspects of Birth Control,” Mother Earth 11, no. 2 (1916): 468 475.

120 Wilhem Reich, Die Funktion des Orgasmus: Zur Psychopathologie und zur Soziologie des Geschlechtslebens (Vienna: Internationaler Psychoanalytischer Verlag, 1927); Wilhelm Reich, Die sexuelle Revolution: Zur charakterlichen Selbststeuerung des Menschen (Frankfurt am Main: Fischer, 1966).

121 Emma Goldman, “The Element of Sex in Life,” n.d., EGP-IISH, No. 213, 7-8.

122 Ibid., 12. 
itations: "The man rarely starves sexually. The flourishing business of prostitution is proof for that." 123 It was traditions, like marriage, that demanded this kind of self-restriction for women because "[s]ociety demands that the young adult man and woman (especially woman) shall repress the sex-impulse for a number of years-often for the whole of their life."124 The common opinion therefore emphasized that "[s]ex is disgraceful for nice girls," were supposed to preserve their virginity for marriage instead of freeing their body and mind by experiencing sexual pleasure. While women consequently suffered from marriage and other role-model-related restrictions, "[m]ost men are brought up to believe that woman must be taken and not give herself gladly and joyously in love and passion. That also prevents the more sensitive of the male species to give themselves freely-they are afraid to outrage and shock the sensibilities and innocence of their wives."126

As long as sex was supposed to be a taboo for women and not a pleasure to enjoy, there was neither a chance for emancipation nor one for a revolution that could change society as a whole. Or, as Goldman worded it with regard to the negative impact of sexual restrictions:

Take frigidity in some women largely due to the deadening effect of the sex taboo. Such women cannot even if they try desperately respond to the sex urge in the man. In fact, the very thought of the sexual embrace to such women is torture. Even if the man lacks refinement and imposes his needs on his wife he will find no satisfaction. In the end he seeks gratification elsewhere. There is quite a percentage of married men among the clientele of prostitution. Sex is more powerful than all decisions. The man will grow indifferent and in the end insist on divorce. ${ }^{127}$

Goldman consequently asked for an unlimited and unconditional sexual liberation for women: "Let us get rid of the mock modesty so prevalent on the surface of polite society, let us liberate sex from falsehood and degradation." ${ }^{128}$ It is unfortunate that this liberation has not yet been achieved and that countless women around the world still suffer from the same exploitation of their sexuality with regard to labor-related and marriage-related exploitation by capitalism and men alike.

\footnotetext{
123 Ibid., 14.

124 Ibid., 15.

125 Ibid., 21.

126 Ibid., 24.

127 Ibid., 26-27.

128 Ibid., 50.
} 


\section{Conclusion}

Emma Goldman, as a strong anarchist woman, "wanted a world without jealousy, insecurity, or possessiveness, and she fought those feelings in herself, with limited success." ${ }^{129}$ Having experienced the exploitation of women in the US garment industry as well as a rather unsuccessful marriage, she knew how hard it was for female workers and wives to gain equality and freedom. Goldman therefore dedicated her political struggle as an anarchist toward a revolution that would free women and men alike, because only as equal partners would they be able to change the world. When Goldman fought against the traditional idea of marriage, as it had been representing the yoke that prevented women from liberation, she without any doubt fought against the exploitation of the idea of love as a precondition for human relationships, but not love as such. Goldman loved her life, and she wanted women to love themselves as well. A free sexual experience of love and pleasure was important for the passionate revolutionary, as it was essential for the female anarchist that the individual freedom of women was not limited by antiquated and outdated models of companionship, i.e. marriage.

However, many of her demands came too early, and Goldman would not live long enough to witness the consequences of some of her demands in later years. Yet, when she wrote to Rose Pesotta, an anarcha-feminist union organizer and vice-president of the International Ladies Garment Workers Union, in 1935, Goldman had not given up her hope that the anarchist movement would eventually be able to trigger change: "Yes, our movement is in a bad state. The old ones have either died out or have become hoary with age. And the young ones are in the Communist ranks. There is unfortunately no one who could gather them up even if they were interested in our ideas. My only consolation is the certainty that the present trend to dictatorship is not for all times. Our ideas will have their day in the world court, though I may not live to see it. You are so much younger, you probably will." ${ }^{130}$ The fact that Goldman's writings were revived in the second half of the 20th century and continue to appeal to feminists all over the world even today highlights how important her ideas were with regard to true emancipation based on freedom and equality. One can therefore only hope that Goldman's demands will eventually be addressed in the 21st century, liberating women and men alike to face the causes for the existence of sorrow and misery in the world: exploitation and inequality, which is unfortunately still, around a century after Goldman expressed her thoughts, a gender inequality.

129 Ferguson, "Gender and Genre," 751.

130 Emma Goldman to Rose Pesotta, Montreal, March 7, 1935, EGP-IISH, No. 129, 2. 


\title{
Works Cited
}

\section{Unpublished Sources}

\author{
International Insitute for Social History, Amsterdam, The Netherlands \\ Emma Goldman Papers
}
Tamiment Library and Robert F. Wagner Labor Archives, New York University, New York City, NY, United States of America

Alexander Berkman Papers, TAM.067

\section{Published Primary and Secondary Works}

"A Woman Anarchist." In Emma Goldman. A Documentary History of the American Years, vol. 1: Made for America, 1890-1901, edited by Candace Falk et al., 243-246. Urbana/Chicago, IL: Illinois University Press, 2008.

“Goldman's Cry Against Society." In Emma Goldman: A Documentary History of the American Years, vol. 1: Made for America, 1890-1901, edited by Candace Falk et al., 249. Urbana/Chicago, IL: University of Illinois Press, 2008.

Avrich, Paul. The Haymarket Tragedy. Princeton, NJ: Princeton University Press, 1984.

Avrich, Paul and Karen Avrich. Sasha and Emma: The Anarchist Odyssey of Alexander Berkman and Emma Goldman. Cambridge, MA: Harvard University Press, 2012.

Berkman, Alexander. “A Greeting.” Mother Earth 1, no. 4 (1906). Accessed October 17, 2019. http://dwardmac.pitzer.edu/Anarchist_Archives/goldman/ME/mev1n4.html.

Berkman, Alexander. Prison Memoirs of an Anarchist. New York: Mother Earth, 1912.

Brossat, Alain and Sylvia Klingberg. Revolutionary Yiddishland: A History of Jewish Radicalism. Translated by David Fernbach. London/New York: Verso, 2016.

DeLamotte, Eugenia C. Gates of Freedom: Voltairine de Cleyre and the Revolution of the Mind. Ann Arbor, MI: University of Michigan Press, 2004.

Drinnon, Richard. Rebel in Paradise: A Biography of Emma Goldman. Phoenix edition. Chicago: University of Chicago Press, 1982 [1961].

Drinnon, Richard and Anna Maria Drinnon, eds. Nowhere at Home: Letters from Exile of Emma Goldman and Alexander Berkman. New York: Schocken Books, 1975.

Falk, Candace. Love, Anarchy, and Emma Goldman. Rev. ed. New Brunswick, NJ: Rutgers University Press, 1990 [1984].

Falk, Candace et al., eds. Emma Goldman: A Documentary History of the American Years, vol. 1: Made for America, 1890-1901. Urbana/Chicago, IL: University of Illinois Press, 2008.

Ferguson, Kathy E. “Discourses of Danger: Locating Emma Goldman.” Political Theory 36, no. 5 (2008): $735-761$.

Ferguson, Kathy E. “Gender and Genre in Emma Goldman." Signs 36, no. 3 (2011): 733-757. 
Foucault, Michel. Fearless Speech. Edited by Joseph Pearson. Los Angeles: Semiotext(e), 2001.

Franks, Benjamin, Nathan Jun and Leonard Williams, eds. Anarchism: A Conceptual Approach. New York/London: Routledge, 2018.

G.[oldman], E.[mma]. “Alexander Berkman.” Mother Earth 1, no. 3 (1906): 22-24. Accessed October 17, 2019. http://www.gutenberg.org/files/27262/27262-h/27262-h.htm\#Page_22.

Goldman, Emma. Living My Life. New York: Knopf, 1931. Accessed December 17, 2018. https:// theanarchistlibrary.org/library/emma-goldman-living-my-life.

Goldman, Emma. "Marriage." In Emma Goldman: A Documentary History of the American Years, vol. 1: Made for America, 1890-1901, edited by Candace Falk et al., 269-273. Urbana/Chicago, IL: Illinois University Press, 2008.

Goldman, Emma. Marriage and Love. New York: Mother Earth, 1911.

Goldman, Emma. "The New Woman." In Emma Goldman: A Documentary History of the American Years, vol. 1: Made for America, 1890-1901, edited by Candace Falk et al., 322 - 323. Urbana/Chicago, IL: Illinois University Press, 2008.

Goldman, Emma. "The Social Aspects of Birth Control." Mother Earth 11, no. 2 (1916): $468-475$

Goldman, Emma. “The Tragedy of Women's Emancipation.” Mother Earth 1, no. 1 (1906): 9-18, http://dwardmac.pitzer.edu/Anarchist_Archives/goldman/ME/mev1n1.html\#tra.

Goldman, Emma. The White Slave Traffic. New York: Mother Earth, 1909.

Goldman, Emma. "Walt Whitman. 1916. "In The Emma Goldman Papers: A Microfilm Edition, edited by Candace Falk with Ronald J. Zborayetal, reel 54. Alexandria, VA: Chadwyck-Healey, 1990.

Goldman, Emma. "What Is There in Anarchy for Woman?" In Emma Goldman: A Documentary History of the American Years, vol. 1: Made for America, 1890-1901, edited by Candace Falk et al., 289-292. Urbana/Chicago, IL: Illinois University Press, 2008.

Goldman, Emma and Alexander Berkman. "Our Sixth Birthday." Mother Earth 6, no. 1 (1911). Accessed February 26, 2020. http://dwardmac.pitzer.edu/Anarchist_Archives/goldman/ $\mathrm{ME} / \mathrm{mev6n1.html.}$

Gornick, Vivian. Emma Goldman: Revolution as a Way of Life. New Haven, CT: Yale University Press, 2011.

Haaland, Bonnie. Emma Goldman: Sexuality and the Impurity of the State. Montréal et al.: Black Rose Books, 1993.

Hemmings, Clare. "In the Mood for Revolution: Emma Goldman's Passion.” New Literary History 43, no. 3 (2012): 527-545.

Hemmings, Clare. "Sexual Freedom and the Promise of Revolution: Emma Goldman's Passion." Feminist Review 106 (2014): 43-59.

Herzer, Manfred. Magnus Hirschfeld und seine Zeit. Berlin: De Gruyter, 2017.

Ishill, Joseph. Emma Goldman: A Challenging Rebel. Berkeley Heights, NJ: Oriole Press, 1957. Jacob, Frank. "An Anarchist Revolution? Emma Goldman as an Intellectual Revolutionary." Journal for the Study of Radicalism 15, no. 2 (2021). Forthcoming.

Jacob, Frank. "Anarchism and the Perversion of the Russian Revolution: The Accounts of Emma Goldman and Alexander Berkman." Diacronie 33, no. 1 (2018): https://doi.org/10. 4000/diacronie.7405.

Jacob, Frank. "Anarchismus, Ehe und Sex: Emma Goldman (1869-1940) als Anarcha-Feministin." In Geschlecht und Klassenkampf: Die "Frauenfrage" aus deutscher 
und internationaler Perspektive im 19. und 20. Jahrhundert, edited by Vincent Streichhahn and Frank Jacob., 202-221. Berlin: Metropol, 2020.

Jacob, Frank. "Anarchistische Imperialismuskritik und staatliche Repression: Emma Goldman, Alexander Berkman und die Kritik an der politischen Ökonomie des Ersten Weltkrieges in den USA, 1917-1919." Prokla 50, no. 201 (2020): 681-695.

Jacob, Frank. "Der Anarchismus und die Russische Revolution - Emma Goldman und Alexander Berkman im Kampf gegen den Bolschewismus." Ne znam: Zeitschrift für Anarchismusforschung 7 (2018): 3-66.

Jacob, Frank. Emma Goldman and the Russian Revolution: From Admiration to Frustration Berlin: De Gruyter, 2020.

Jacob, Frank. Emma Goldman: Die Identitäten einer Anarchistin. Berlin: Hentrich \& Hentrich, 2021.

Jacob, Frank. Emma Goldman: Ein Leben für die Freiheit. Berlin: Hentrich \& Hentrich, 2021.

Jacob, Frank. “Emma Goldmans Blick auf Bolschewismus, Faschismus und Nationalsozialismus: Eine anarchistische Perspektive auf den Totalitarismus der 1920erund 1930er-Jahre." Zeitschrift für Geschichtswissenschaft 68, no. 10 (2019): 833-847.

Jacob, Frank. "From Aspiration to Frustration: Emma Goldman's Perception of the Russian Revolution." American Communist History 17, no. 2 (2018): 185-199.

Jacob, Frank. "Radical Trinity: Anarchist, Jew, or New Yorker?” In Jewish Radicalisms: Historical Perspectives on a Phenomenon of Global Modernity, edited by Frank Jacob and Sebastian Kunze, 153-180. Berlin: De Gruyter, 2019.

Kensinger, Loretta. "Radical Lessons: Thoughts on Emma Goldman, Chaos, Grief, and Political Violence Post-9/11/01." Feminist Teacher 20, no. 1 (2009): 50-70.

Kowal, Donna M. "Anarcha-Feminism.” In The Palgrave Handbook of Anarchism, edited by Carl Levy and Matthew S. Adams, 265-279. Cham: Palgrave Macmillan, 2019.

Kowal, Donna M. Tongue of Fire: Emma Goldman, Public Womanhood, and the Sex Question. Albany, NY: SUNY Press, 2016.

Marso, Lori Jo. "A Feminist Search for Love: Emma Goldman on the Politics of Marriage, Love, Sexuality and the Feminine." Feminist Theory 4, no. 3 (2003): 305-320.

McKinley, Blaine. “'The Quagmires of Necessity': American Anarchists and Dilemmas of Vocation." American Quarterly 34, no. 5 (1982): 503-523.

Michels, Tony. A Fire in Their Hearts: Yiddish Socialists in New York. Cambridge, MA/London: Harvard University Press, 2005.

Mohammed, Jowan A. "Mary Hunter Austin und die Forderungen nach einer Veränderung der Geschlechterrollen in den USA, 1914-1918." In Geschlecht und Klassenkampf: Die "Frauenfrage" aus deutscher und internationaler Perspektive im 19. und 20. Jahrhundert, edited by Vincent Streichhahn and Frank Jacob, 222-239. Berlin: Metropol, 2020.

Moritz, Theresa and Albert Moritz. The World's Most Dangerous Woman. Vancouver: Subway Books, 2001.

Nicholas, Lucy. "Gender and Sexuality." In The Palgrave Handbook of Anarchism, edited by Carl Levy and Matthew S. Adams, 603-621. Cham: Palgrave Macmillan, 2019.

Porter, David, ed. Vision on Fire: Emma Goldman on the Spanish Revolution. 3rd ed. New Paltz, NY: Commonground Press, 1985 [1983].

Presley, Sharon and Crispin Sartwell. Exquisite Rebel: The Essays of Voltairine De CleyreAnarchist, Feminist, Genius. Albany, NY: State University of New York Press, 2005. 
Pribanic-Smith, Erika J. and Jared Schroeder. Emma Goldman's No-Conscription League and the First Amendment. New York: Routledge, 2019.

Reich, Wilhem. Die Funktion des Orgasmus: Zur Psychopathologie und zur Soziologie des Geschlechtslebens. Vienna: Internationaler Psychoanalytischer Verlag, 1927.

Reich, Wilhelm. Die sexuelle Revolution: Zur charakterlichen Selbststeuerung des Menschen. Frankfurt am Main: Fischer, 1966.

Rofel, Lisa. "Queer Positions, Queerying Asian Studies.” Positions 20, no. 1 (2012): 183-193. Sheehan, Sean. Anarchism. London: Reaktion, 2003.

Shulman, Alex Kates. "Introduction." In Red Emma Speaks: Selected Writings and Speeches by Emma Goldman, edited by Alex Kates Shulman. New York: Vintage Books, 1972.

Streichhahn, Vincent. "Zur 'Frauenfrage' und Sozialdemokratie im deutschen Kaiserreich: Zwischen Antifeminismus und Emanzipation." In Geschlecht und Klassenkampf: Die "Frauenfrage" aus deutscher und internationaler Perspektive im 19. und 20. Jahrhundert, edited by Vincent Streichhahn and Frank Jacob, 48-77. Berlin: Metropol, 2020.

Weiss, Penny A. and Loretta Kensinger, eds. Feminist Interpretations of Emma Goldman. University Park, PA: Pennsylvania State University Press, 2007.

Wexler, Alice. Emma Goldman: An Intimate Life. New York: Pantheon Books, 1984.

Zimmer, Kenyon. Immigrants against the State: Yiddish and Italian Anarchism in America. Urbana, IL: Illinois University Press, 2015 